\title{
Makaleler
}

\section{Türk Sermaye Piyasasında Bilgi Suistimali ve Piyasa Dolandirrcliğı Suçu Düzenlemelerinin İrdelenmesi}

\section{Aysel GÜNDOĞDU'}

Makale Gönderim Tarihi: 03.10.2016

Makale Kabul Tarihi: 30.05.2017

\section{Öz}

Sermaye piyasası hukukunda "Bilgi suistimali ve piyasa dolandırıcılığı", finansal piyasaların en önemli ayaklarından biri olan sermaye piyasasının "güven" unsurunun zedelenmesine yol açmaktadır. Özelikle bireysel yatırımcıların alım-satım yapmaktan çekinmesine neden olan yapay fiyat hareketleri ve gerçekdıșı bilgi, haberlerin yayılması sermaye piyasasının baș etmeye çalıștı̆ı sorunlardır. Çalıșmanın amacı, yürürlükteki 6362 sayılı Sermaye Piyasası Kanunu kapsamında bilgi suistimali ve piyasa dolandırıcılığı suçlarının eski ve yeni fiillerini, yaptıımlarını irdelemektir.

Anahtar Kelimeler: Sermaye Piyasası, Bilgi Suistimali, Piyasa Dolandırıcılığı, Manipülasyon.

\section{Analysis of Regulation Market Abuse and Insider Dealing In Turkish Capital Market}

\section{Abstract}

"Investor confidence and equality of opportunity" that is the basic element for the development of the capital market should

Yrd.Doç.Dr., İstanbul Medipol Üniversitesi, İșletme ve Yönetim Bilimleri Fakültesi, Bankacılık ve Sigortacılık Bölümü, agundogdu@medipol.edu.tr orcid.org/00000003-2638-9694 
be given to ensure the transparency quality of market regulation. In the capital markets law, Information market abuse and insider dealing lead to damage of the capital market "confidence". The purpose of this paper is to investigate of market abuse and insider dealing in the new Capital Market Law No. 6362.

Key Words: Capital Market, Market Abuse, Insider Dealing, Manipulation.

\section{Gíriș}

Sermaye piyasasında yatırım, beklentiler üzerine yapılır. Yatırımcının beklentilerini olușturan unsur ise "bilgi"dir. Sermaye piyasasında fiyatlar, bilgi ve beklentilerin belirlediği doğrultuda olușmaktadır. Piyasa ve ilgili menkul kıymet hakkında olumlu haberler getiri beklentilerini arttıracak ve fiyatlar yukarı yönlü hareket edecektir. Aksi durumda ise geleceğe yönelik getiri beklentileri azalacak ve fiyatlar așağı yönlü hareket edecektir. Bu nedenle, piyasada olușabilecek herhangi bir bilgi asimetrisi yatırımcının güvensizliğine sebebiyet verebilir. Diğer yandan, sermaye piyasasında bilgi asimetrisi haksız kazanca yol açmaktadır. Etkin piyasa hipotezine göre, bilgi asimetrisi zayıf ve yarı zayıf formda piyasa modellerinde rastlanan bir sorundur. Kuvvetli formda olan piyasalarda bilgiye herkes eșit zaman ve maliyette ulașabilmektedir. Bilgiye eșit ulașabilmek, sermaye piyasalarının șeffaflı̆ını yansıtmaktadır. Yatırımcıların tümünün bilgiyi aynı anda ve eksiksiz edinmesi, sermaye piyasasının amacına ulașmasını sağlar.

Sermaye piyasasının gelișmesi ve etkinliğinin sağlanabilmesi, toplumun bu konuda yeterli bilgi ile donatılması ile mümkündür. Finansal olaylar konusunda aydınlatılmayan bir toplum, tasarruflarını sermaye piyasası dıșına yönlendirebilir. Özellikle bireysel tasarruf sahiplerinin sermaye piyasasının ișlevleri konusunda aydınlatılması önem tașımaktadır (Taner ve Akkaya, 2012).

Sermaye piyasasında fiyat, yatırımcının karar verme sürecindeki en önemli bilgidir. Fiyatların düzgün ve gerçekçi bir biçimde tespit edilmesi, doğru bilginin olușması açısından önemlidir. Bir menkul kıymetin ortaya çıkıșı arz ve talep gibi doğal koșullara dayanmıyorsa, yatıımcının yanlıș karar vermesine ve piyasaya 
güveninin kaybolmasına yol açabilir. Bu sebeple, güveni zedeleyici hareketler, sermaye piyasasının likidite sağlama ve küçük sermayelerin ekonomiye yayılmasını zorlaștırmaktadır. Bununla birlikte, yeni yatırımcıların pay piyasasına girișine engel olmaktadır (Bayındır, 2011).

Türk sermaye piyasasında bilgi suiistimali ve piyasa dolandırıcılığı suçlarından dolayı yatıımcılara ișlem yasağı getirilmektedir. 2001-2013 yılları arasında ișlem yasağı getirilen yatııımclar kișilikleri açısından incelendiğinde, ișlem yasağı getirilenlerin 104'ünün tüzel kiși, 3373'inin ise gerçek kiși olduğu görülmektedir. İșlem yasağı getirilen gerçek kișilerin \%87,6'sını erkekler, \%12,4'ünü kadınlar olușturmaktadır (Çalıșkan, 2015).

6362 sayılı Sermaye Piyasası Kanunu ile gelen yeni düzenlemeler ile ilgili yapılan akademik çalıșmalar sınırlıdır. Bu nedenle çalıșmanın literatüre katkıda bulunacağı beklenmektedir. Dayan (2014) çalıșmasında yeni Sermaye Piyasası Kanunu'nun genel olarak değerlendirmiș, bilgi suiistimali ve piyasası dolandırıcılığı gibi suçlarının düzenlenmesine yer vermiș̦tir. Yıldııım (2014) çalıșmasında Türk sermaye piyasası suçları kapsamında etkin pișmanlık konusunu incelemiștir. 6362 sayılı Sermaye Piyasası Kanunu'nda piyasa dolandırıcılığı ve güveni kötüye kullanma suçları açısından ekonomik suça ekonomik ceza yaklașımı çerçevesinde etkin pișmanlık hükümleri öngörülmüștür. Erdoğan ve Sancak (2016) makalelerinde Türk sermaye piyasasında önceden ișlemlere karșı yeni yaklașımlar ve piyasa üzerinde olası etkilerini incelemișlerdir.

Bu çalıșmanın amacı ise yürürlükteki 6362 sayılı Sermaye Piyasası Kanunu kapsamında bilgi suistimali ve piyasa dolandırıcılığı suçlarının eski ve yeni fiillerini, yaptıımlarını irdelemektir.

\section{Sermaye Piyasalarında Piyasa Dolandırıalığı Suçu}

Sermaye piyasasında eski adı manipülasyon, yeni adı piyasa dolandııcılığı olan suç niteliğindeki eylemi, alım satım ișlemleri ile sanal bir görünüm yaratarak diğer yatıımcıların alım satım payları üzerinde etkili olma șeklinde tanımlanabilir (Downes ve Goodman, 2010). Diğer bir tanıma göre ise; piyasa dolandırıcılığı, menkul kıymetlerin fiyatlarının manipülatörler tarafından hile- 
li davranıșlarla belirli bir seviyenin üzerine çıkarılmak istenmesi, belirli bir seviyenin altına düșürülmek istenmesi ya da olduğu gibi sabitlenmek istenmesi dolayısı ile gerçekleștirilen faaliyetlere verilen addır (Yüce, 2012).

Piyasa dolandırıcılığı kanun düzenlemeleri açısından ișlem bazlı piyasa dolandırıcılığı ve bilgi bazlı piyasa dolandırıcılığı olmak üzere iki alt bölümde incelenebilir:

a) Ișlem Bazlı Piyasa Dolandırııılığı: İșlem bazlı piyasa dolandırıcılığı niteliği tașıyan ișlemler; șüpheli alım satım yapma, șüpheli emir verme, șüpheli emir iptal etme, șüpheli emir değiștirme veya hesap hareketi gerçekleștirme olabilir. İșlem bazlı piyasa dolandırıcılığı yapıldığına dair belirli șüpheli ișlem ve davranıș kalıpları vardır. Bunlar: (SPK V-102.1 Nolu Tebliğ, 2014)

- Bir kiși veya birlikte hareket eden kișiler tarafından belirli bir payın fiyatını sabit tutmaya dönük pozisyon alınması, payın ișlem miktarı ve emir büyüklüklerine göre arz ve talebine etki edecek veya fiyatını değiștirecek büyüklükte emirler verilmesi veya ișlemler gerçekleștirilmesi sonucunda piyasanın yanıltılması.

- Bir kiși veya birlikte hareket eden kișiler tarafından, piyasanın genel ișlem karakterine uyumlu olmayan surette, normal finansal gerekçelerle açıklanamayacak șekilde farklı piyasalarda (korunma amacıyla açıklanamayacak aynı yönlü vadeli ișlem sözleșmesi, opsiyon ve spot ișlem alımı-satımı) büyük ölçekte ișlemler gerçekleștirilerek piyasanın yanıltılması.

İșlem bazlı piyasa dolandırıcılığının ortaya çıkarılması için uzun bir zaman dilimi içerisinde piyasa fiyatlarının ve alıș-satıș ișlemlerinin takip etmesi, hatta vadeli ișlem piyasalarındaki ișlemlere dahi dikkat edilmesi gerekmektedir. Ancak her bir yatırımcının alım-sałım ișlemlerini, anlık göstergeleri ya da vadeli ișlem piyasasındaki hareketleri sürekli takip ederek piyasa dolandırıcılığının olasılığını hesaplamak kolay değildir (Tarkun vd., 2014). Farklı istatistiki modeller kullanılarak piyasa dolandırıcılığının varlığı test 
edilebilmektedir. Fındık ve Öztürk (2016) çalıșmalarında Beneish Modeli kullanılarak BIST imalat sanayinde ișlem gören șirketlerin bilgi bazlı piyasa dolandırıcılığı uygulayıp uygulamadıklarını tespit etmișlerdir.

a) Bilgi Bazlı Piyasa Dolandırıcılığı: Bilgi bazlı piyasa dolandırıcılığında ise yalan, yanlıș, aldatıcı, bilgi verme, söylenti çıarma, haber yapma, yorum yapma, rapor hazırlama ve bu bilgileri yayma birer șüpheli ișlemdir. Bilgi bazlı piyasa dolandırııılığı yapıldığına dair belirli șüpheli ișlem ve davranıș kalıpları vardır. Bunlar: (SPK V-102.1 Nolu Tebliğ, 2014)

- Belirli bir pay hakkında yatıımcıların kararlarını etkileyici nitelikte, herhangi bir dayanağı olmayan yalan, yanlıș veya yanıltıcı bilgi vermek.

- Belirli bir payda pozisyon alındıktan sonra piyasada yanıltıcı haberler yaymak suretiyle yatırımcıların kararlarını ve dolayısıyla payların fiyatını etkilemeye dönük faaliyetlerde bulunulması.

Her iki piyasa dolandırıcılığı suçunda da yapılan ișlemler sonucunda sermaye piyasası aracının fiyatına, değerine, arz ve talebine, yatırımcının kararına etki etmiș olması gerekmektedir. Diğer bir ifade ile sadece șüpheli ișlemin yapılmıș olması suçun unsurunu olușturmamaktadır. Șüpheli ișlemin sonucunda ortada bir etki, değișim olması da aranmakładır.

\section{Sermaye Piyasalarında Bilgi Suistimali Suçu}

Literatürde "içeriden öğrenenlerin ticareti" olarak geçen bilgi suistimali suçunun fiili, önemli bir bilginin kamuya açıklanmasından önce bu bilginin lehte ișlem yapılarak haksız kazanç sağlanması olarak tanımlanmaktadır. Örneğin; bir halka açık maden șirketi yeni bir rezerv altın bulduğunu kamuya açıklamadan önce șirket genel müdürü șirket payından satın alıp sonra bilgiyi kamuya açıklar ve bu ișleminden kazanç sağlar ise burada bilgi suistimali suçu söz konusudur (Sancak, 2014). Șirketin piyasa değerini etkileyebilecek nitelikte her türlü bilginin kamuyu aydınlatma ilkesi 
doğrultusunda halka duyurulması gerekmektedir. Bu durum, sermaye piyasasının temelini olușturan "güven" unsuru için son derece önemli bir husustur.

6362 sayılı Kanun'da düzenlenen bilgi suistimali suçu için ekonomik anlamda temel unsur, alıșverișin taraflarından birinin diğerine göre ișlem konusu varlığın değeri hakkında önceden daha fazla bilgiye sahip olmasıdır. Asimetrik bilgi nedeniyle taraflardan biri alıcı ve diğeri satıcı olarak zıt kutupta yer alarak mal ve hizmet alıș verișini gerçekleștirmektedirler (Kesici, 2014).

Bir sermaye piyasası aracına ilișkin her türlü bilgi, anılan suçun konusunu olușturmamaktadır. Söz konusu suça vücut verecek bilgi, belli özelliklere sahip bir bilgidir. Bu nedenle hangi tür bilgilerin anılan suçun olușumuna sebebiyet verecek nitelikte olduğunun belirlenmesi konunun açıklanması açısından önem arz etmektedir (Șenol, 2012). Bilgi suistimali yapıldığına dair belirli șüpheli ișlem ve davranıș kalıpları vardır. Bunlar: (SPK V-102.1 Nolu Tebliğ, 2014)

- Bir müșterinin hesap açar açmaz veya uzun bir süredir ișlemi olmadığı halde belirli bir payda net alım yönünde ișlemler gerçekleștirmesi, bu ișlemlerin hızlı bir șekilde tamamlanması için aceleci davranması, bu ișlemler sonrasında söz konusu payla ilgili önemli bir gelișmenin yașanması ve fiyatın yükselmesinin ardından müșterinin söz konusu payları satarak kısa bir süre içerisinde normal olmayan bir kazanç elde etmesi

- İçsel bilgiye erișimi olabilecek bir kișinin, genel ișlem karakterine uyumlu olmayan surette, halka açוk bir șirketi ilgilendiren önemli bir gelișmenin öncesinde ve/veya sonrasında halka açık șirket paylarında alım veya satım ağılıklı ișlem gerçekleștirerek menfaat elde etmesi,

- Telefonla veya doğrudan müșteri temsilcisine sözlü olarak emirlerin iletimi sırasında veya ișlemler gerçekleștikten sonraki süreçte yatırımcının söz, ifade, davranıș, tutum ve emirlerinin zamanlamasından hareketle halka açık bir șirketi ilgilendiren içsel bilgiye veya sürekli bilgiye diğer 
yatırımcılardan önce sahip olduğu yönünde izlenim edinilmesi.

\section{Türk Sermaye Piyasasında Piyasa Dolandırıcılığı ve Bilgi Suistimali Suçuna Dair Düzenlemeler}

Sermaye Piyasası Kurulu tarafından 21 Ocak 2014 tarih ve 28889 sayılı Resmi Gazetede yayımlanarak yürürlüğe giren "Bilgi Suistimali veya Piyasa Dolandırııılığı Suçları Hakkında Bildirim Yükümlülüğü Tebliği (V-102.1)" Türk sermaye piyasasında ișlenebilecek bu suçları önleyebilmek amacı ile düzenlenmiștir. Tebliğe göre, yatırım kurulușları șüpheli gördükleri ișlemleri 5 ișgünü içerisinde Sermaye Piyasası Kurulu'na bildirmek zorundadırlar. Ayrıca, yatıım kurulușları her türlü ortamdaki belgeleri düzenlenme tarihinden, defter ve kayıtları ise son kayıt tarihinden itibaren sekiz yıl süre ile saklamak ve istenmesi halinde Sermaye Piyasası Kurulu'na vermek zorundadırlar.

Türk sermaye piyasasındaki yasa değișikliği nedeni ile bilgi suistimali ve piyasa dolandırıcılığı suçlarına dair hükümler yeniden düzenlenmiștir. Tablo 1'de yürürlükten kalkan 2499 sayılı Sermaye Piyasası Kanunu'nda ve yürürlükteki 6362 sayılı Sermaye Piyasası Kanunu'nda bilgi suistimali suçunun fiiline ve yaptırmına yer verilmiștir. Tabloda da görüleceği üzere, 6362 sayılı Sermaye Piyasası Kanunu ile bilgi suistimali suçunun fiili daha açık bir biçimde tanımlanmıștır. Yapılan bu yeni tanımda bilginin hangi yollar ile suistimal edilebileceği tarif edilmiștir. Yürürlükten kalkan 2499 sayılı Sermaye Piyasası Kanunu'nda içeriden öğrenenlerin ticareti olarak geçen piyasa bozucu nitelikteki bu eylem, "sermaye piyasası araçlarının değerini etkileyebilecek" olarak açıklanırken; yeni düzenleme ile bu ifadeye "doğrudan veya dolaylı olarak" ve "ihraççוlar hakkında" ifadeleri de eklenmiștir.

Yeni düzenleme ile sermaye piyasasında bilgi suistimali suçunun yaptırımında adli para cezasının alt limiti dıșında önemli bir değișiklik olmadığı görülmektedir. 2499 sayılı Sermaye Piyasası Kanunu'nda hem hapis cezası hem de adli para cezası uygulanırken; yeni düzenlemede "veya" ifadesi eklenmiș olup iki seçenek arasındaki karar yargıya bırakılmıștır. Diğer bir nokta ise, yeni 
düzenlemede adli para cezasının tabanı elde edilen menfaatin üç katından iki katına indirilmiș olmasıdır.

Tablo 1: Bilgi Suistimali Suçunun Eski ve Yeni Sermaye Piyasası

Kanunu'nda Yer Alan Fiili ve Yaptırımı

\begin{tabular}{|c|c|c|c|}
\hline & Suçun Adı & Suçun Fiili & Yaptırım \\
\hline $\begin{array}{l}6362 \\
\text { Sayılı } \\
\text { Yeni } \\
\text { Sermaye } \\
\text { Piyasası } \\
\text { Kanunu }\end{array}$ & Bilgi Suistimali & $\begin{array}{l}\text { Doğrudan ya da dolaylı olarak ser- } \\
\text { maye piyasası araçları ya da ihraççı- } \\
\text { lar hakkında, ilgili sermaye piyasası } \\
\text { araçlarının fiyatlarını, değerlerini } \\
\text { veya yatırımcıların kararlarını etkile- } \\
\text { yebilecek nitelikteki ve henüz kamuya } \\
\text { duyurulmamıș bilgilere dayalı olarak } \\
\text { ilgili sermaye piyasası araçları için } \\
\text { alım ya da satım emri vermek veya } \\
\text { verdiği emri değiștirmek veya iptal et- } \\
\text { mek ve bu suretle kendisine veya bir } \\
\text { bașkasına menfaat temin etmek }\end{array}$ & $\begin{array}{l}2 \text { yıldan } 5 \text { yıla kadar hapis } \\
\text { VEYA adli para cezası ile } \\
\text { cezalandırılılar. Ancak, bu } \\
\text { suçtan dolayı adli para ce- } \\
\text { zasına hükmedilmesi halin- } \\
\text { de verilecek ceza elde edi- } \\
\text { len menfaatin iki katından } \\
\text { az olamaz. }\end{array}$ \\
\hline \begin{tabular}{|l}
2499 \\
Sayılı \\
Eski \\
Sermaye \\
Piyasası \\
Kanunu
\end{tabular} & $\begin{array}{l}\text { İçeriden } \\
\text { Öğrenenlerin } \\
\text { Ticareti }\end{array}$ & $\begin{array}{l}\text { Sermaye piyasası araçlarının değe- } \\
\text { rini etkileyebilecek, henüz kamuya } \\
\text { açıklanmamıș bilgileri kendisine veya } \\
\text { üçüncü kișilere menfaat sağlamak } \\
\text { amacıyla kullanarak sermaye piyasa- } \\
\text { sında ișlem yapanlar arasındaki fırsat } \\
\text { eșitliğini bozacak șekilde mameleki } \\
\text { yarar sağlamak veya bir zararı ber- } \\
\text { taraf etmek }\end{array}$ & $\begin{array}{l}2 \text { yıldan } 5 \text { yıla kadar hapis } \\
\text { ve } 5.000 \text { günden } 10.000 \\
\text { güne kadar adlî para ceza- } \\
\text { sı. Para cezaları üst sınırla } \\
\text { bağlı olmaksızın suçun ișlen- } \\
\text { mesi suretiyle temin edilen } \\
\text { menfaatin üç katından az } \\
\text { olamaz. }\end{array}$ \\
\hline
\end{tabular}

Tablo 2'de yürürlükten kalkan 2499 sayılı Sermaye Piyasası Kanunu'nda ve yürürlükteki 6362 sayılı Sermaye Piyasası Kanunu'nda piyasa dolandırıcılığı suçunun fiiline ve yaptırımına yer verilmiștir. Piyasa dolandırıcılığı suçu, bilgi bazlı ve ișlem bazlı olarak gerçekleștirilebileceğinden tabloda ayrı ayrı incelenmiștir. 6362 sayılı Sermaye Piyasası Kanunu ile bilgi bazlı piyasa dolandırıcılığının fiilinde "rapor hazırlama" ifadesi eklenmiș olup bu durumun uygulamada karıșıklığa sebep olacağı endișesini doğurmuștur. Diğer yandan, bilgi bazlı piyasa dolandırıcılığı suçunun yaptırımında hapis cezası ile adli para cezası arasında seçim yapma durumu söz konusu değildir. Eski düzenlemede adli para cezası suçun ișlenmesi ile elde edilen menfaatin üç katından az olmayacağı șeklinde iken yeni düzenlemede adli para cezasının tabanı menfaatin kendisi ile sınırlandırılmıștır. 
İșlem bazlı piyasa dolandırıcılığında ise yeni düzenlemede suçun fiilinin nasıl gerçekleșebileceği "alım veya satım yapmak, emir vermek, emir iptal etmek, emir değiștirmek veya hesap hareketleri gerçekleștirmek" ifadeleri ile daha açık tanımlanmıștır. Yeni düzenlemede ișlem bazlı piyasa dolandırıcılığının yaptııımında hapis cezası aynı bırakılmıș olup adli para cezasının üst sınırı kaldırılmıștır.

Tablo 2: Piyasa Dolandırıcılığı Suçunun Eski ve Yeni Sermaye Piyasası Kanunu'nda Yer Alan Fiili ve Yaptırımı

\begin{tabular}{|c|c|c|c|}
\hline & Suçun Adı & Suçun Fili & Yaptırım \\
\hline $\begin{array}{l}6362 \\
\text { Sayılı } \\
\text { Yeni } \\
\text { Sermaye } \\
\text { Piyasası } \\
\text { Kanunu } \\
\end{array}$ & $\begin{array}{l}\text { Bilgi Bazlı } \\
\text { Piyasa } \\
\text { Dolandırıcııı̆ı }\end{array}$ & $\begin{array}{l}\text { Sermaye piyasası araçlarının fi- } \\
\text { yatlarını, değerlerini veya yatırım- } \\
\text { cıların kararlarını etkilemek ama- } \\
\text { cıyla yalan, yanlıș veya yanılıcı } \\
\text { bilgi veren, söylenti çıkaran, } \\
\text { haber veren, yorum yapan veya } \\
\text { rapor hazırlayan ya da bunları } \\
\text { yayanlar }\end{array}$ & $\begin{array}{l}2 \text { yıldan } 5 \text { yıla kadar hapis VE } \\
\text { bes bin günden on bin güne } \\
\text { kadar adli para cezası ile ce- } \\
\text { zalandırılırlar. Ancak, bu suçtan } \\
\text { dolayı verilecek olan adli para } \\
\text { cezasının miktarı, suçun ișlenme- } \\
\text { si ile elde edilen menfaatten az } \\
\text { olamaz. }\end{array}$ \\
\hline $\begin{array}{l}2499 \\
\text { Sayılı } \\
\text { Eski } \\
\text { Sermaye } \\
\text { Piyasası } \\
\text { Kanunu }\end{array}$ & $\begin{array}{l}\text { Bilgi } \\
\text { Manipülasyonu }\end{array}$ & $\begin{array}{l}\text { Sermaye piyasası araçlarının } \\
\text { değerini etkileyebilecek, yalan, } \\
\text { yanlıș, yanıltıcı, mesnetsiz bilgi } \\
\text { veren, haber yayan, yorum ya- } \\
\text { pan ya da açıklamakla yükümlü } \\
\text { oldukları bilgileri açılamayan } \\
\text { gerçek kișilerle, tüzel kișilerin yet- } \\
\text { kilileri ve bunlarla birlikte hareket } \\
\text { etmek }\end{array}$ & $\begin{array}{l}2 \text { yıldan } 5 \text { yıla kadar hapis + } \\
5000 \text { günden } 10000 \text { güne ka- } \\
\text { dar adlî para cezası. Para ceza- } \\
\text { ları üst sınırla bağlı olmaksızın } \\
\text { suçun ișlenmesi suretiyle temin } \\
\text { edilen menfaatin üç katından az } \\
\text { olamaz. }\end{array}$ \\
\hline $\begin{array}{l}6362 \\
\text { Sayılı } \\
\text { Yeni } \\
\text { Sermaye } \\
\text { Piyasası } \\
\text { Kanunu }\end{array}$ & $\begin{array}{l}\text { Bazlı } \\
\text { dırıcııı̆ı }\end{array}$ & \begin{tabular}{|l|} 
Sermaye piyasası araçlarının \\
fiyatlarına, fiyat değișimlerine, \\
arz ve taleplerine ilișkin olarak \\
yanlıș veya yanıltıcı izlenim uyan- \\
dırmak amacıyla alım veya satım \\
yapmak, emir vermek, emir iptal \\
etmek, emir değiștirmek veya he- \\
sap hareketleri gerçekleștirmek
\end{tabular} & $\begin{array}{l}2 \text { yıldan } 5 \text { yıla kadar hapis + } \\
5000 \text { güne kadar adli para ce- } \\
\text { zası }\end{array}$ \\
\hline $\begin{array}{l}2499 \\
\text { Sayılı } \\
\text { Eski } \\
\text { Sermaye } \\
\text { Piyasası } \\
\text { Kanunu } \\
\end{array}$ & $\begin{array}{l}\text { İșlem } \\
\text { Manipülasyonu }\end{array}$ & $\begin{array}{l}\text { Yapay olarak, sermaye piyasası } \\
\text { araçlarının, arz ve talebini etki- } \\
\text { lemek, aktif bir piyasanın varlığı } \\
\text { izlenimini uyandırmak, fiyatlarını } \\
\text { aynı seviyede tutmak, arttırmak } \\
\text { veya azaltmak amacıyla alım ve } \\
\text { satımını yapan gerçek kișilerle, tü- } \\
\text { zel kișilerin yetkilileri ve bunlarla } \\
\text { birlikte hareket etmek }\end{array}$ & $\begin{array}{l}2 \text { yıldan } 5 \text { yıla kadar hapis + } \\
5000 \text { günden } 10000 \text { güne ka- } \\
\text { dar adlî para cezası. Para ceza- } \\
\text { ları üst sınırla bağlı olmaksızın } \\
\text { suçun ișlenmesi suretiyle temin } \\
\text { edilen menfaatin üç katından az } \\
\text { olamaz. }\end{array}$ \\
\hline
\end{tabular}


6362 sayılı Sermaye Piyasası Kanunu'nda sermaye piyasası alanında ișlenebilecek suç tipleri yönünden yaptırım olarak fiilin ağırlığı da gözetilerek, sadece hapis cezasına yahut hapis cezası ile birlikte adli para cezasına veyahut adli para cezasıyla seçimlik olarak hapis cezasına yer verilen bir yaptıım sistemi benimsenmiștir. Özellikle para cezasının tayini yönünden, çıkar amaçlı fiillerin niteliği dikkate alınarak elde edilen menfaat ile uyumlu bir sistem belirlenmeye çalıșılmıștır (Yenidünya, 2012). Yürürlükte olan 6362 sayılı Sermaye Piyasası Kanunu, piyasa dolandırıcılığı suçuna dair bazı farklılıklar içermektedir. Bunlar (TKYD, 2014):

- Suçun maddi unsuru genișletilmiștir. Alım satım yapılmasının yanı sıra, emir verme, değiștirme ve hesap hareketi gerçekleștirmek de, suçun olușmasına imkân verecektir.

- Ișleme dayalı piyasa dolandırıılığı için aktif pișmanlık hükmü getirilmiștir.

- Bilgiye dayalı piyasa dolandırıcılığına ilișkin mevcut yapı büyük ölçüde korunmuștur. Ancak, kamuya açıklamakla yükümlü olan bilgilerin açıklanmaması, suçun unsurları arasından çıkartılmıștır.

Tablo 1 ve 2'deki bilgi suistimali ve piyasa dolandırıcılığı suçlarının yaptırımları karșılașısıııldığında 2499 sayılı Sermaye Piyasası Kanunu'nda her iki suç türü için de aynı yaptırımların söz konusu olduğu; oysa 6362 sayılı Sermaye Piyasası Kanunu'nda her iki suç türü ve piyasa dolandırıcılığının iki farklı türü için bile farklı yaptırımların düzenlendiği görülmektedir. Diğer bir dikkat çeken nokła ise, eski düzenlemede idari para cezaları menfaatin üç katından az olmazken, yeni düzenlemede bilgi suistimali için idari para cezası menfaatin iki katından, bilgi bazlı piyasa dolandırıcılığı için ise menfaatten az olamaz ifadesi yer almaktadır. Bașka bir ifade ile yeni düzenlemede adli para cezası tabanı indirilmiștir.

6362 sayılı Sermaye Piyasası Kanunu 107. maddenin üçüncü fıkrasına göre, bilgi bazlı piyasa dolandırıcılığında bulunanlara pișmanlık göstererek, beș yüz bin Türk Lirasından az olmamak 
üzere, elde ettiği veya elde edilmesine sebep olduğu menfaatin iki katı miktarı kadar parayı;

- Henüz sorușturma bașlamadan önce Hazineye ödediği takdirde, hakkında ceza hükmü verilmez.

- Sorușturma evresinde ödediği takdirde, verilecek ceza yarısı oranında indirilir.

- Kovușturma evresinde hüküm verilinceye kadar ödediği takdirde, verilecek ceza üçte biri oranında indirilir.

Sermaye piyasasında bilgi suistimali ve piyasa dolandırıcıllğı sayılmayan bazı haller de vardır. Bunlar (6362 s. SP K. m. 108):

- Merkez Bankası ya da yetkilendirilmiș bașka bir resmî kurum veya bunlar adına hareket eden kișiler tarafından para, döviz kuru, kamu borç yönetim politikalarının uygulanması veya finansal istikrarın sağlanması amacıyla ișlem yapılması,

- SPK düzenlemelerine göre uygulanan geri alım programları, çalıșanlara pay edindirme programları ya da ihraççı veya bağlı ortaklığının çalıșanlarına yönelik diğer pay tahsis edilmesi

- SPK'nın fiyat istikrarını sağlayıcı ișlemlere ve piyasa yapıcılığına ilișkin düzenlemelerine uygun olarak sermaye piyasası araçlarının alım veya satımının yapılması yahut emir verilmesi veya emir iptal edilmesi

\section{Sermaye Piyasasında Piyasa Dolandırıcılığı ve Bilgi Suistimali Suçunu Engellemek İçin Uluslararası Düzenlemeler}

1983 yılında kurulan Uluslararası Menkul Kıymetler Komisyonları Örgütü, dünyadaki menkul kıymet düzenleyicilerini bir araya getiren, küresel standart koyucu uluslararası bir organdır. Özellikle G20 ülkeleri ve Finansal İstikrar Kurulu ile çalıșan örgütün "Sermaye Piyasası Düzenlemelerinin Amaç ve ilkeleri" adlı raporunda sermaye piyasasının korunmasını üç temel ilkeye dayandı- 
rılmaktadır. Bunlar: yatırımcının korunması, piyasaların adil, etkin ve șeffaf olmasını sağlama, sistemik riskin azaltılmasıdır (IOSCO, 2003). Sermaye piyasalarında piyasa dolandırıcılığı ve bilgi suistimali hallerinin suç sayılması doğrudan yatırımcının korunması ilkesine dayanmaktadır.

Dünyanın birçok ülkesinde menkul kıymetler piyasalarında piyasa dolandırıcılığı ve bilgi suistimali yapılmaktadır. Teknolojinin gelișmesi, serbest hareketliliğin olması nedeni ile alıcı ve satıcılar değișik piyasalara girmișlerdir. AB Konseyi tarafından Avrupa ülkeleri için geçerli olan Sermaye Yeterliliği Direktifi kabul edilmiștir. Amerika'da ise Sermaye Piyasası Kurulu piyasa düzenleme ve denetleme ișlemlerini yürütmektedir. Amerika'da ilk defa 1934 yılında piyasa dolandırıcılığını önleyici tedbirler alınmıștır (Kutukız, 1999). Amerikan Sermaye Piyasası Kurulu'nun ilkelerine göre, ülkede sermaye piyasası bilgi suistimali suçunun yaptırımı azami 20 yıl hapis cezası, bireyler için azami 5 milyon \$ ve halka açık ortaklıklar için azami 25 milyon \$ para cezası söz konusudur (SEC, 2014). Çin'de bilgi suistimali 1970'li yılların bașından beri yasaklanmıștır. Buna rağmen 2002 yılında yasal olarak suç fiili olarak kabul edilmiștir. Bilgi suistimali suçunun yaptırımı, en fazla 10 milyon \$ ve 10 yıl hapis cezasıdır (Yan, 2013). Ülkelerin sermaye piyasalarındaki piyasa bozucu eylemler için düzenledikleri cezalar incelendiğinde görülmektedir ki dünyada bu tür suçların yaptırımında uygulanan ortak bir karar yoktur. Her ülke, yasal düzenlemeleri doğrultusunda kendi hükümlerini uygulamaktadır.

\section{Sonuç}

Sermaye piyasasında her bilgi, finansal aracın fiyatını doğrudan etkileyebilir. Bunun en temel nedeni; sermaye piyasasında yatııımın beklenti üzerine yapılmasıdır. Yatırımcılar, sermaye piyasası aracının piyasa değerinin gelecekte düșebileceği ya da yükselebileceği beklentisi ile karar almaktadırlar. Etkin piyasa hipotezine göre, her yatıııcı yatırım yaptığı finansal aracın bilgisine eșit șartlarda ulaștığında mükemmel piyasa ortamı olușmaktadır. Ancak burada tanımlanan piyasa, arzu edilen piyasa modeli olup gerçekte her yatırımcı bilgiye eșit zaman ve maliyette ulașama- 
maktadır. Bu sebeple sermaye piyasasında asimetrik bilgi sorunu sık sık karșılașılan bir durumdur. Bu sorun, potansiyel yatırımcıların piyasada alım-satım yapmaya endișe duymasına neden olmaktadir.

Özellikle bireysel yatırımcılar ile kurumsal yatırımcıların bilgiye ulașma, bilgiyi yorumlama ve yatırıma dönüștürmedeki imkân ve becerileri eșit değildir. Bilgiye ulașamayan, ulașsa bile doğru yorumlamayan yatırımcıların "dolandırılması" ve kurumsal yatırımcıların bilgiyi kamuya açıklamadan önce kendi menfaatleri doğrultusunda kullanması ile "bilgi suistimali" durumları ortaya çıkmaktadır. Sermaye piyasasının ihtiyacı olan "güven" unsurunu sarsan bu iki durum, sadece yatırımların artmasını engellememekte aynı zamanda, dolaylı da olsa, uzun vadede ülke ekonomisine de zarar vermektedir. Bu noktada, sermaye piyasasını düzenleyen ve denetleyen otorite ve tamamlayıcı nitelikte olan diğer resmi kurumlar devreye girmektedir.

Henüz ołuz yıllık bir geçmiși olan Türk sermaye piyasasında hem kurumsal hem de bireysel yatıımcının güveni kazanılamamıstır. 6362 sayılı yeni Sermaye Piyasası Kanunu'nda bilgi suistimali ve piyasa dolandırıcılığı suçunun yeniden düzenlenme ihtiyacı bu sebepledir. Ancak, AB düzenlemeleri çerçevesinde kapsamlı olarak yeniden tanımlanan bu suçların yaptırımında önemli değișiklikler sağlanabildiğini söylemek güçtür. Nitekim bilgi suistimali ve piyasa dolandırıcılığı gibi piyasa bozucu eylemlerin tespiti kolay olmayıp bu suçların yargı süreci sorunlu geçmektedir.

Türk sermaye piyasasındaki yasa değișikliği nedeni ile bilgi suistimali ve piyasa dolandırıcılığı suçlarının düzenlemesinde farklılıklar bulunmaktadır. 6362 sayılı Sermaye Piyasası Kanunu ile bilgi suistimali suçunun fiili daha açık bir biçimde tanımlanmıștır. Yapılan bu yeni tanımda bilginin hangi yollar ile suistimal edilebileceği tarif edilmiștir. Yürürlükten kalkan 2499 sayılı Sermaye Piyasası Kanunu'nda içerinden öğrenenlerin ticareti olarak geçen piyasa bozucu nitelikteki bu eylem, "sermaye piyasası araçlarının değerini etkileyebilecek" olarak açıklanırken; yeni düzenleme ile bu ifadeye "doğrudan veya dolaylı olarak" ve "ihraççılar hakkın$\mathrm{da}^{\prime \prime}$ ifadeleri de eklenmiștir. 
Yeni düzenleme ile sermaye piyasasında bilgi suistimali suçunun yaptırımında adli para cezasının alt limiti dıșında önemli bir değișiklik olmadığı görülmektedir. 2499 sayılı Sermaye Piyasası Kanunu'nda hem hapis cezası hem de adli para cezası uygulanırken; yeni düzenlemede "veya" ifadesi eklenmiș olup iki seçenek arasındaki karar yargıya bırakılmıșıı. Diğer bir nokta ise, yeni düzenlemede adli para cezasının tabanı elde edilen menfaatin üç katından iki katına indirilmiș olmasıdır.

6362 sayılı Sermaye Piyasası Kanunu ile bilgi bazlı piyasa dolandırıcılığının fiilinde "rapor hazırlama" ifadesi eklenmiș olup bu durumun uygulamada karıșıkığa sebep olacağı endișesini doğurmuștur. Diğer yandan, bilgi bazlı piyasa dolandırıcılığı suçunun yaptırımında hapis cezası ile adli para cezası arasında seçim yapma durumu söz konusu değildir. Eski düzenlemede adli para cezası suçun ișlenmesi ile elde edilen menfaatin üç katından az olmayacağı șeklinde iken yeni düzenlemede adli para cezasının tabanı menfaatin kendisi ile sınırlandırılmıștır. İșlem bazlı piyasa dolandırıcılığında ise yeni düzenlemede suçun fiilinin nasıl gerçekleșebileceği "alım veya satım yapmak, emir vermek, emir iptal etmek, emir değiștirmek veya hesap hareketleri gerçekleștirmek" ifadeleri ile daha açık tanımlanmıștır. Yeni düzenlemede ișlem bazlı piyasa dolandıııcılığının yaptırımında hapis cezası aynı bırakılmıș olup adli para cezasının üst sınırı kaldırılmıı̦tır.

Bilgi suistimali ve piyasa dolandırıcılığı suçunun yaptırımları karșılaștırıldığında 2499 sayılı Sermaye Piyasası Kanunu'nda her iki suç türü için de aynı yaptırımların söz konusu olduğu; oysa 6362 sayılı Sermaye Piyasası Kanunu'nda her iki suç türü ve piyasa dolandırıcılığının iki farklı türü için bile farklı yaptırımların düzenlendiği görülmektedir. Diğer bir dikkat çeken nokta ise, eski düzenlemede idari para cezaları menfaatin üç katından az olmazken, yeni düzenlemede bilgi suistimali için idari para cezası menfaatin iki katından, bilgi bazlı piyasa dolandırıcılığı için ise menfaatten az olamaz ifadesi yer almaktadır. Bașka bir ifade ile yeni düzenlemede adli para cezası tabanı indirilmiștir. Ayrıca, bilgi bazlı piyasa dolandırıcılığında bulunanlara pișmanlık gösterenler için çeșitli indirim oranları düzenlenmiștir. 
Sermaye piyasasındaki piyasa bozucu eylemlerden olan bilgi suistimali ve piyasa dolandırıcılığı suçlarının yeni ve eski düzenlemeleri ile ilgili genel bir değerlendirme yapıldığında, yeni düzenlemede her iki suçun fiilinin daha net açıklandığı; eski düzenlemede tek tip olan yaptıımın yeni düzenlemede her suç türü için ayrı ayrı düzenlendiği görülmektedir. Güven temelli olan sermaye piyasası gibi bir mekanizmanın daha ağır yaptırımlar ile düzenlenmesi gerekirken, 6362 sayılı yeni Sermaye Piyasası Kanunu'ndaki pișmanlık hükmü ve eski düzenlemede yer alan idari para cezasının menfaatin üç katından az olamayacağı yaptırımın düșürülmesi ile bu durumun tersi gerçekleșmiș, her iki suçun yaptırımı da çeșitli șekillerde hafifletilmiștir.

Türk sermaye piyasasının gelișimi için yurtiçi bireysel ve kurumsal tasarrufların sermaye piyasasına dahil edilmesi oldukça önemlidir. Sermaye piyasamızın çoğunluğu yabancı ve sınırlı bir yatırımcı kitlesi ile ișlem yaptı̆̆ı bir gerçektir. Son yıllarda yurtiçi tasarruf oranının \% 12 'lere çekildiği Türkiye'nin uzun vadeli yatırım bilincine ihtiyacı vardır. Sermaye piyasası ve borsanın "kumar" ve "tüyo" ifadeleri ile özdeșleștirildiği Türkiye'de tasarruf sahiplerinin piyasa bakıșının olumlu yönde değișmesi gerekmektedir. Türkiye'de sermaye piyasasının itibarının sağlanması ancak bu algının değișimi ile mümkündür. Söz konusu algının değișmesi ise yatıımcının korunması ilkesi doğrultusunda piyasada ișlenecek suçların önüne geçilmesi, ișlenen suçların da caydırıcı etkide bir yaptırım sistemi ile cezalandırılması ile sağlanabilir. Bu bağlamda, sermaye piyasasının piyasa bozucu eylemleri belirlemek, teșhis etmek ve bu eylemlere yaptırım uygulamak için iyi bir düzenleme, iyi bir denetleme ve konusunda uzman hızlı bir yargı sürecine gereksinim vardır. 


\section{KAYNAKLAR}

Bayındır, S. 2011. Türk Sermaye Piyasası Hukukunda Manipülasyon Suçu. Beta Yayıncılık. İstanbul.

Çalıșkan, M.T. 2015. Borsa İstanbul'da Manipülasyon: 2001 - 2013 Yılları Arasında İșlem Yasaklıların Profili. Yönetim ve Ekonomi Araștırmaları Dergisi - Cilt: 13 Sayı: 1.

Dayan, V. 2014. Yeni Sermaye Piyasası Kanunu Üzerine Bir İnceleme. Uluslararası Yönetim İktisat ve İșletme Dergisi, Cilt 10, Sayı 23.

Downes, J. Goodman ve Jordan, E. 2010. Dictionary Of Finance And Investment Term. Barron's Financila Guides. Eighth Edition. New York.

Erdoğan, O. Sancak, E.I. 2016. Türk Sermaye Piyasasında Önceden İșlemlere Karșı Yeni Yaklașımlar ve Yeni Yaklașımların Piyasa Üzerinde Olası Ełkileri. Finansal Araștırmalar ve Çalıșmalar Dergisi. Cilt:8, Sayı:14.

Fındık, H. ve Öztürk, E. 2016. Finansal Bilgi Manipülasyonunun Beneish Modeli Yardımıyla Ölçülmesi: BIST İmalat Sanayi Üzerine Bir Araștırma. İșletme Araștırmaları Dergisi. 8/1, ss.483-499.

Kesici, E. 2014. Bilgi Suistimali Suçu, Suça Ilișkin Tedbirler ve Alınan Tedbirlerin Etkinliği. İstanbul Üniversitesi Sosyal Bilimler Enstitüsü, Yayınlanmamıș Yüksek Lisans Tezi.

Kutukız, D. 1999. Menkul Kıymet Piyasalarında Manipülasyon ve İstanbul Menkul Kıymet Borsası'nda Manipülasyon Önlemleri. Selçuk Üniversitesi Sosyal Bilimler Meslek Yüksekokulu Dergisi. Cilt 2.

International Organization of Securities Commissions, Objectives and Principles of Securities Regulation. 2003. https://www.iosco.org/library/pubdocs/pdf/IOSCOPD154.pdf, (15.09.2016)

Sancak, E. 2014. Sermaye Piyasası Sözlüğü: Önemi 101 Kavram. Scala Yayıncilık. İstanbul.

Securities And Exchange Commission, 2013 Insider Trading Policy, http:// www.sec.gov/Archives/edgar/data/25743/000138713113000737/ ex14_02.htm, (05.09.2016)

Șenol, C. 2012. İçeriden Öğrenilen Bilgi ve İçeriden Öğrenen Kavramlarının Ceza Hukuku Açısından İncelenmesi. Hacettepe Hukuk Fakültesi Dergisi. 2(2).

Taner, B. ve Akkaya G. C. 2012. Sermaye Piyasası Faaliyet Alanı ve Menkul Kıymetler. Yenilenmiș İkinci Baskı. Detay Yayıncılık. Ankara. 
Tarkun, S. Ergür, H.O. Aydın A.F. 2014. İșlem Bazlı Manipülasyon Șirketlerinin Vektör Otoregresif Analizi İle İncelenmesi. Akademik Yaklașımlar Dergisi. Cilt: 5 Sayı: 1

TKYD. 2014. Yeni Sermaye Piyasası Kanunu ve Piyasalara Bakıș Açısı.

Yan, A. 2013. Insider Dealing Law in Hong Kong. Centre for Financial Regulation and Economic Development Working Paper No. 13.

Yenidünya, C. 2012. Sermaye Piyasası Kanununda Düzenlenen Suç ve Kabahatlere Illișkin Genel Prensipler. İpek Yolu Canlanıyor: Türk-Çin Hukuk Zirvesi.

Yıldırım. E. 2014. Sermaye Piyasası Suçları Açısından Etkin Pișmanlık. Ankara Barosu Dergisi. Sayı:2.

Yüce, A. A. 2012. Sermaye Piyasasında Manipülasyon. Türkiye Barolar Birliği Dergisi. Sayı:98.

21 Ocak 2014 Tarih ve 28889 Sayılı Resmi Gazete "Bilgi Suistimali veya Piyasa Dolandırıcılığı Suçları Hakkında Bildirim Yükümlülüğü Tebliği (V-102.1)"

30.12.2012 Tarih ve 28513 Sayılı Resmi Gazete'de Yayınlanan 6362 sayılı Sermaye Piyasası Kanunu

30.07.1981 Tarih ve 17416 Sayılı Resmi Gazete'de Yayınlanan 2499 sayılı Sermaye Piyasası Kanunu 
